\title{
DE93 004584
}

\section{LANDBOOK}

\section{High-Level Radioactive Waste Transportation}

\section{DISCLAIMER}

eport was prepared as an account of work sponsored by an agency of the United States nment. Neither the United States Government nor any agency thereof, nor any of their yees, makes any warranty, express or implied, or assumes any legal liability or responsifor the accuracy, completeness, or usefulness of any information, apparatus, product, or s disclosed, or represents that its use would not infringe privately owned rights. Refererein to any specific commercial product, process, or service by trade name, trademark, acturer, or otherwise does not necessarily constitute or imply its endorsement, recomtion, or favoring by the United States Government or any agency thereof. The views pinions of authors expressed herein do not necessarily state or reflect those of the I States Government or any agency thereof.

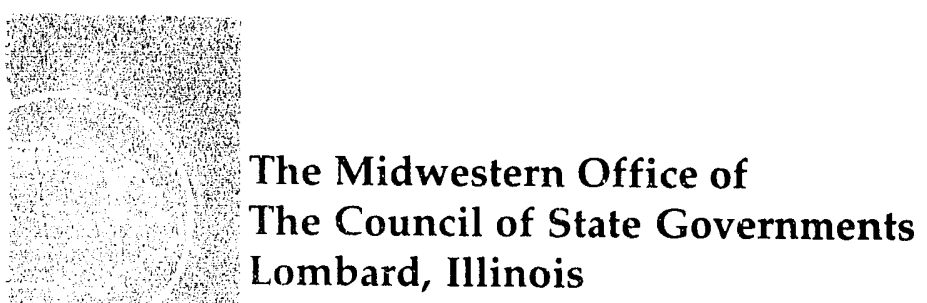




\section{The Council of State Governments}

For more than half a century, The Council of State Govermments has served as a common ground for the states of the nation. The (ouncil is a non-profit, statesupported and-directed serviceorganization that provides research and resomees, identifie's trends, supplies answers and creates a network for legislative, executive and judicial branch representatives.

Through its mational headquarters in Lexington, Kentucky, a state-federal office in Washington, D.C., and regional offices in New York, Atlanta, Chicago (Lombard) and San Francison, CSC is dedicated to preserving the role of states in America's federal system.

The role of the Midwestern Office of CSC $\mathrm{i}$ is to foster intergovermmental cooperation through the promotion of regiomal, as well as individual, state responses to common issues and challenges.

\section{Handbook of High-Level Radioactive Waste Transportation}

This report was prepored with the support of the U.S. Department of Energy, Cooperatioe Agreement Vo. DE-FC(1)-86C1110402. However, any opinions, findings. conclusions or recommendations expressed herein are those of the author(s) and do not necessarily reflect the riews of $100 \mathrm{OE}$.

The purpose of the agreement, and reports issued pursuant to it, is to identify and analyze regiomal issues pertaining to the transportation of high-level radioactive waste and to inform Midwestern state officials with respect to technical issues and regulatory concerns related to waste tramsportation.

In addition to publishing reports related to the transportation of high-level radioactive Waste, the Midwestern Office of the CSG has compiled a reference library on radioactive waste transportation. All materials are available by loan. For more information, contact CSC-MW at $708 / 81(1-(1) 210$.

Prepared by:

Lisa R. Sattler, Policy Analyst

Midwestern Office of The Council of State Governments

641 E. Butterfield Road, Suite 401

Lombard, IL 6(1)148-5651

(71)8) $810-(1210$

\section{ii - High-Level Radioactive Waste}




\section{Table of Contents}

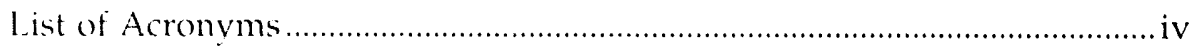

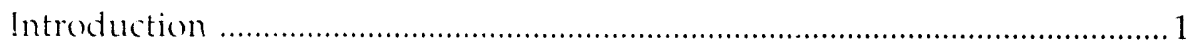

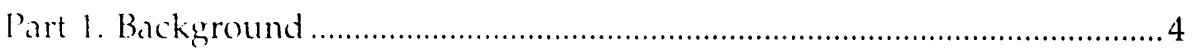

The Development of U.S. Policy on

Radioactive Waste Disposal ................................................4

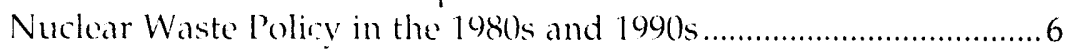

Part 2. OCRWM's Transportation System ...................................................

Transportation Business Plan .......................................................... 10

Cask Design and Testing ...................................................... 10

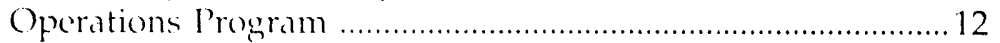

Transportition Institutional l'lan .................................................. 14

Modal Mix ............................................................................ 14

Overweight Truck Shipments ................................................ 15

Highway Routing .............................................................. 16

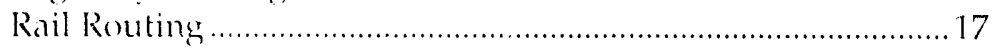

Safeguarding Shipments .................................................... 18

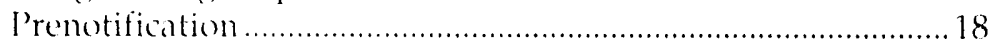

Transportation Infrastructure .............................................. 19

Inspection and Enforcement ................................................20

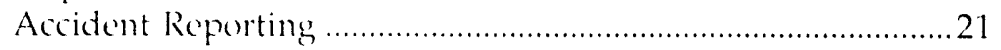

Emergency Preparedness and Response ................................. 22

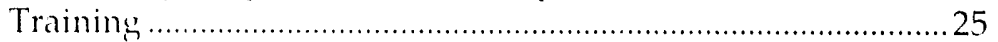

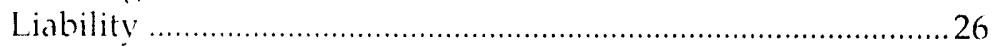

State, Tribal and local Regulation of

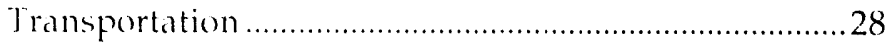

Appendix A. Selected Federal and State Law's and Regulations Related to Radioative Materials Transportation ....................30

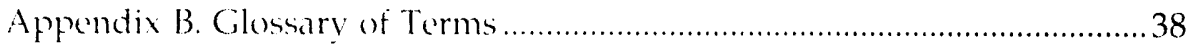

Midwestern High-Level Radioactive Waste

Transportation Project Publications List ................................43 


\section{List of Acronyms}

AEC - Atomic Energy Commission

BWR - Boiling Water Reactor

CSG-MW - The Council of State Governments, Midwestern Office

CVSA - Commercial Vehicle Safety Alliance

DOE - U.S. Department of Energy

DOT - U.S. Department of Transportation

EPA - Envirommental Protection Agency

ERDA - Energy Research and Development Administration

FEMA - Federal Emergency Management Agency

FRERP - Federal Radiological Emergency Response Plan

FRMAP - Federal Radiological Monitoring and Assessment Plan

GAO - U.S. General Accounting Office

HMTA - Hazardous Materials Transportation Act

HMTUSA - Hazardous Materials Transportation Uniform Safety Act

NRC - U.S. Nuclear Regulatory Commission

NWF - Nuclear Waste Fund

NWN - Nuclear Waste Negotiator

NWPA - Nuclear Waste Policy Act of 1982

OCRWM - Office of Civilian Radioactive Waste Management (DOE)

PWR - Pressurized Water Reactor

STAA - Surface Transportation Assistance Act

TBP - Transportation Business Plan

TCG - Transportation Coordination Group

TEC - Transportation External Coordination

TEPP - Transportation Emergency Preparedness Plan

TIP - Transportation Institutional Plan

WIPP - Waste Isolation Pilot Plant

iv - High-Level Radioactive Waste 


\section{Introduction}

The High-Lerel Radioaction Waste Transportation Handbook serves as a reference to which state officials and members of the general public may turn for information on radioactive waste transportation and on the federal government's svstem for transporting this waste under the Civilian Radioactive Waste Management Program. The Hond thook condenses and updates information contained in the Midae'stern High-Le'el Radionction Waste Transportation Primer. It is intended primarily to assist legislators who, in the future, may be called upon to enact legislation pertaining to the transportation of radioactive waste through their jurisdictions.

The Handbolk is divided into two sections. The first section places the federal government's program for transporting radioactive waste in context. It provides background information on nuclear waste production in the United States and traces the emergence of federal policy for disposing of radioactive waste. The second section covers the history of radioactive waste transportation; summarizes major pieces of legislation pertaining to the transportation of radionctive waste; and provides an overview of the radioactive waste transportation program developed by the U.S. Department of Energy (DOE). To supplement this information, a summary of pertinent federal and state legislation and a glossary of terms are included as appendices, as is a list of publications produced by the Midwestern Office of The Council of State Governments (CSG-MW) as part of the Midwestern righ-Level Radioactive Waste Transportation Project.

While the Handbook focuses on economic and institutional aspects of the transportation program, a review of the pohical issues may be equally important for understanding the climate in which the more technical decisions are made. There is general consensus within the scientific community that storage, disposal and transportation of spent fuel and high-level radioactive waste can be accomplished in a safe manner, but various public opinion surveys over the years have revealed that a significant number of American citizens think otherwise. Some studies have found respondents to be skeptical of the federal government's ability to manage a radioactive waste disposal program, often expressing a belief that the government does not care about public concerns or questions about safe disposal. Several studies have identified state legislators and of ficials as the individuals most trusted by citizens to represent their interests.

These findings both reflect and exacerbate the "not-in-my-backyard" (NIMBY') sentiment, which has long impeded the federal government's attempts to site facilities for disposing of waste. The identification of potential sites for disposing of or storing waste has generated opposition in communities or states that 
are under consideration. To date, not much public outery has been raised over the transportation component of the Civilian Radioactive Waste Management Program. One DOE proposes routes for transporting rationctive waste, public opposition will be more likely to materialize, particularly along prospectioe transportation corridors.

Improving the public's confidence and trust in the federal government requires a good deal of both time and effort. While the U.S. Nuclear Regulatory Commission (NRC) and its predecessor agencies have worked toward ensuring the safety of the nuclear power industry, growing awareness of serious waste management problems at DOE's weapons production facilities represents a potential public relations liability for Dor:

To demonstrate its commitment to public and environmental safety, and thereby facilitate public acceptance, DOE has moved away from the practice of "decide-announce-defend," whereby decisions regarding site selection were made virtually without public imput. As directed by the Nuclear Waste Policy Act (NWI'A), D()E works with state, tribal and local governments to involve the public in devising its strategy for dereloping and operating the Civilian Radioactive Waste Management Program.

Public participation may facilitate acceptance of the transportation prosram by providing affected citizens and units of government a voice in the program's development and operation. Physical constraints remain the primary criteria for routing and handling shipments - that is, tramsporting high-level waste over unimproved roads to a woid centers of population would not be considered teasible. Yed the cultivation of public input mave an indication that political considerations aregaining ground on economic concerns. For instance, testing scalle models of waste transport casks to verify their ability to withstand accidents is deemed sufficient from a scientific standpoint; howerer, griven the high degree of public concern, many groups have urged DOE to invest in full-size models for testing to provide an extra margin of safety and increase public confidence.

Although DOE has expressed a desire to include the public in decisionmaking, some of DOE's activities have led many individuals to question its commitment to this policy. In the process of siting the national nuclear waste repository per (ongressional mandate, the state of Nevata has accused DOE: af ignoring the steadfast opposition of its citizens and govermment officials to hosting the facility. Lnder the NWI'A, however, a state's protest is only valid once a site has been recommended to and approved by Congress - steps that will be laken only after an extensive array of site characterization studies have been completed. 
This type of conflict may arise in the transportation component of the Civilian Radioactive Waste Management Program. Potential opposition of state

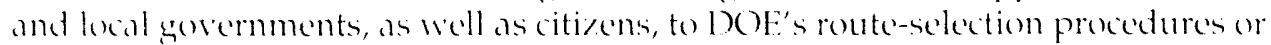
to its safety standards may pose a barrier to implementing the transportation program once facility construction is underway. To minimize the risk of unnecessarily delaying the program, all affected parties-citizens and goremment afficials alse - must be well informed of the legal, regulatory, physical and historical facts pertaining to radioation wate transportation in general and to the federal program in particular. By producing reports such as the lanthose and by responding to repuests for information, the Midwestern Office of The Council of State Covernments works to inform state officials in the Midwest of the facts and to keep them abreast of developments in the federal program and in the states. 


\section{Part 1. Background}

DOE plans to transport two types of highly radioactive waste to facilities for either temporary storage or permanent disposal: spent nuclear fuel from commercial, research and test reactors, and high-level waste produced in the reprocessing of spent fuel. Spent fuel consists of bundles of uranium-filled fuel rods called "assemblies." Because reactor fuel gradually loses its ability to produce enough heat to generate electricity efficiently, fuel assemblies are removed from reactors after about three years of service and are placed in pools of water or dry storage at the reactor site for tempeary storage. Both the water and special shielding protect workers from exposure to radiation and minimize the chance of nuclear fission beconing self-sustaining (see fission in the Glossary).

In the 1960s and early 1970s, reprocessing spent fuel was considered a viable option for maximizing the output of reactor fuel. In addition to conserving uranium resources and lowering the costs of fuel, reprocessing can also reduce the volume of spent fuel requiring disposal. From a national security perspective, however, reprocessing can be highly undesirable: one by-product of the process is plutonium, which can be purified to produce high-grade material for manufacturing nuclear weapons. In 1977, President Carter banned the commercial reprocessing of spent fuel for this reason. Although the Reagan Adminustration removed the ban in 1981, commercial reprocessing remains an unprofitable venture in the U.S.

The reprocessing that has taken place has left quantities of intensely radioactive waste that presently is stored at four sites. High-level waste from commercial reprocessing is stored at West Valley, New York. The other three sites - DOE's Hanford Reservation, Savannah River Site, and Idaho National Engineering Laboratory - store defense-related high-level waste resulting from the reprocessing of spent fuel and other materials from research, naval and weaponsproduction reactors.

\section{The Development of U.S. Policy on Radioactive Waste Disposal}

Due to the potential adverse health effects of exposure to highly radioactive materials, scientists agree that radioactive waste must be isolated from the living environment. This waste was initially intended to be reprocessed. With reprocessing being either unprofitable or illegal, however, utilities began accumulating quantities of spent fuel in temporary storage at reactor sites, creating potential operating and storage problems. 
Every federal agency charged with overseeing the development of nuclear power - from the Atomic Energy Commission (AEC) to DOE - has involved itself in the search for a safe method for disposing of high-level waste. As the commercial nuclear power industry and the nuclear weapons complex flourished, the federal government's commitment to finding a safe disposal method grew as well.

The federal government's official role in the non-military uses of nuclear power began in 1946 with the passage of the Atomic Energy Act. The act established the $A E C$ to regulate and to further the application of nuclear technologies for both military and commercial purposes. The mid-195()s ushered in even greater federal support of nuclear power technology. The 1954 revisions of the Atomic Energy Act allowed for and actively encouraged industrial development of nuclear power, while the Price-Anderson Act of 1957 fostered this development by limiting the personal injury and property damage liability of utilities involved in nuclear accidents. The Price-Anderson Act also insured DOE contractors, government licensees and research universities against the risk of public liability for accidents.

In 1959, Commonwealth Edison's Dresden facility in Morris, Illinois, became the first government-licensed nuclear power plant to be built entirely by industry. By 1972, just 13 years later, 160 orders had been placed for new plants. During this same period, the size of plants increased dramatically. In 1963, the 67megawatt (MWe) Big Rock Point Plant in Charlevoix, Michigan, began operating. Ten vears later, the Tennessee Valley Authority received an operating license for a 1065 -MWe plant in Alabama - a plant with over 15 times the capacity of the Big Rock facility. The tremendous growth of nuclear power generation during the past three decade's has increased the industry's share of total U. S. electricity output from $0.4 \%$ in 1965 to just over $21 \%$ today. As the output of electricity increased, so did the production of high-level radioactive waste and, hence, federal efforts to find a safe method of disposal.

In 1974, Congress dissolved the AEC and created two separate agencies to take over the commission's responsibilities. The Energy Research and Development Administration (ERDA) was charged with promoting the development of the nuclear industry, while regulation of that industry was turned over to the NRC. During the same year, the government initiated the Subseabed Disposal Program to study the feasibility of disposing radionctive waste on the ocean floor. Developing the technology for a geologic repository was the focus of the National Waste Terminal Storage Program (NWTSP), which began in 1976. The search for potential sites for such a repository also started under NWTSP.

Reorganization under the Carter Administration led to the elevation of the FERDA to cabinet status. The newly created DOE continued the work of the 
Subseabed Program and the NWTSP. In 1981, President Reagan issued his Nuclear Policy Statement and in the process set the stage for the development of a comprehensive federal policy for managing the nation's nuclear waste disposal program. The following vear, Congress passed the NWPA, effectively establishing a statutory framework for completing activities that had begun under NWTSP.

\section{Nuclear Waste Policy in the 1980s and 1990s}

The NWPA reyuires DOE to site, construct and operate geologic repositories for the disposal of spent fuel and high-level waste in the United States. Section 304 created the Office of Civilian Radioactive Waste Management (OCRWM) to implement the provisions of the act. To fulfill its responsibilities, OCRWM is required to develop a mission plan to serve as a guide for the waste management program. Other major provisions of the act include the following:

- Subtitle C directs DOE to study the feasibility of monitored retrievable storage (MRS) technology.

- Section 117 provides a system of interaction with affected states and Native American tribes.

- Section 1.37(a)(1) requires adherence to NRC and Department of Transportation (DOT) regulations for waste transportation.

- Section 137(a)(2) mandates the use of private industry for transportation activities whenever possible.

The NWPA authorizes DOE to sign Standard Disposal Contracts (SDCs) for disposal of spent fuel with utilities operating nuclear reactors. Having entered into SDC s covering 76 reactor sites across the country, DOE plans to begin accepting spent fuel for disposal by January 31, 1998. In return, utilities must contribute to the Nuclear Waste Fund (NWF), which provides money for activities related to developing the waste management program. The utilities have paid roughly $\$ 5.6$ billion into the NWF and DOE has contributed $\$ 12.5$ million for disposal of defense wastes, as of June 1992.

To provide for flexibility in the planning process, OCRWM developed three distinct plans for managing radioactive waste. The authorized plan covered the "minimum set of activities" required by the NWPA, primarily the development and operation of a geologic repository and a transportation system for moving spent fuel and high-level waste. The improved-performance plan (currently the base case) expanded the athorized plan, incorporating an MRS facility into the program.

\section{6 - High-Level Radioactive Waste}


Lastly, OCRWM developed contingency plans should technical or political considerations prevent the timely implementation of either of the other plans.

In 1987, the NWIA was amended to redired the Waste management program in a variety of Way's. First, Congress directed DOE to concentrate its site characterization activitien on Yuca Mountain in Nevada and mored the scheduled date for opening the repositery trom legs to 20(1)3. Furthermore, the Amendments Act postponed consideration of a second repository (to be located in the Midwest or in the East) until 20(07. The Amendments Act also authorized DOE to site, construct and operate an MRS facility. The inclusion of an MRS facility will greatly affect decisions regarding the tronsportation system, namely route selection, the number and size of shipments, and the design and construction of transport casks.

Although DOE retains the autherity to identify a site for the MRS facility, the Amendments Act created the Office of the Nuclear Waste Negotiator (NWN) outside DOE to expedite the siting process. The NWN is responsible for working with state, local and tribal geremments to find a site for an MRS facility that is suitable pinysically as well as politically.

The NWN solicited applicitions from state, local and tribal governments for temsibility grants to be used by these governments in deciding whether or not ther would be interested in hosting an MRS facility. The deadline for submitting applicitions for "phase I" grants of 51000,000 clesed lune 30, 1992. A total of 21 Dative Anerican tribes and counties applied for phase l grants, three of which are trom the Vidwest. Cirmt County, North Daketa, had completed the first phase of it - stedy when the commissioners responsible for obtaining the grant were recalled from atfice. The county will not preceed to phase of of the grant process. The Prairie Gland Indian (ommunity of Vinnesota is currently working on its phase I study. The Jomer Brule Sione Tribe in South Dakota has also applied for a phase I grant.

To prevent having the MRS facility become the de facter repository, the Amendments Aet created a link between construction and operation of the MRS tacility and the repository, thereby effectively eliminating several of the continsency plans identified by OCRWM in its 1985 Mission [Pan. This link makes construction and operation of the MRS facility conditional upon the progress of repenitory construction and calls for a halt to MRS facility operations if the eperating license for the repository is revehed or deldved. Furthermore, a limit is phace on the amount of material that can be stored at the MRS facility both before and after the repusitory begins accepting wiaste.

The Secretary of Energy's 1984 reassessment of the Civilian Radioactive Waste Management P'rogram astablished a new target date of 20)1(1) for operation of 


\section{Part 2. OCRWM's Transportation System}

A disposal program centering on one or two national facilities translates into a need to transport radionctive material to and from these sites. For more than 25 vears, high-level radionctive waste has been shipped throughout the country without any fatal accidents or envirommental damage related to the radioactive nature of the cargo. This record of safety holds for both rail and truck shipments.

Spent-fuel shipments have been involved in a variety of DOE-sponsored demonstration projects involving away-from-reactor storage. In 1983, several shipments of spent fuel from utilities in lllinois, Wisconsin and New Jersey destined for reprocessing in West Valley, New York, wore returned to their originating states under court order. Furthermore, radioactive debris has been shipped from Three Mile Island to DOE: S Iaho National Engineering Laboratory near Idaho Falls.

Congress has addressed the transportation of high-level radioactive waste in two major pieces of federal legislation. The Hazardous Materials Transportation Act (HMTA) of 1975 authorized DOT to promulgate regulations for the safe commercial transport of hazardous materials, iricluding radioactive waste. HMTA also included an explicit statement of the authority of the federal government to preempt state and local law's directed at hazardous materials transportation.

Congress revised HMTA in 1990 with the passage of the Hazardous Materials Transportition Liniform Safety Act (HMTUSA). Under the new law, regulations passe: $\quad$ ite, local or tribal govermments that address hazadous Waste transportati a be "substantively the same as" federal regulations to aroid preemption. 11 . I LSA also contains several provisions that deal specifically with the transportation of high-level waste and spent fuel. (For further information on IAMTUSA, see Inspection and Enforiment in this handbook.)

To meet the challenge of developing and safely operating a transportation system of the scale required (o support the Civilian Radioactive Waste Management Program, DOE must find the meansof addressing institutional and technical issues. In 1986, OCRW:M released two separate documents that detailed its plans for developing the transportation program. The Transfontation Busimess Plan (TBI') covered OCRWM's two-phase strategy for developing technical aspects of the transportationsysem, such as the acyuisition of equipment and eperations support

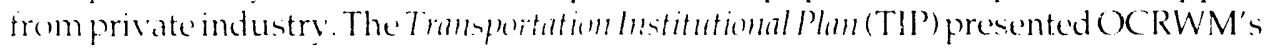
strategl for interacting wis interested partien to identify and resolve issues raised during development and operation of the transportation system. In the Introduc-

\section{Transportation Handbool、 9}


tion to the TIP, DOE stated its intention to combine the TIP and the TBI' into a comprehensive transportation plan in 1987.

In September 1991, DOE issued a draft Mission Plan Amendment, which contained OCRWM's plans for revising the trensportation program. The final version of the Mission Plan Amendment is tentatively scheduled for reledse in late 1992. In the Mission Plan Amendment, DOE reaffirmed its commitment to issuing a comprehensive transportation plan, with the release date set for some time after the final version of the Mission Plan is published. The following discussion draws from the Transportation Business and Institutional Plans, with some changes to reflect program revisions mentioned in the draft Mission Plan Amendment.

\section{Transportation Business Plan}

\section{Cask Design and Tesings}

Casks comprise the first line of defense against public and worker exposure to radiation during normal and emergency transportation situations. Casks must be capable not only of housing and protecting spent fuel, but also of allowing heat to dissipate a d preventing the spent fuel from reaching the point at which fission becomes self-sustaining (see criticality in the Glossary). Existing commercial casks are designed to carry spent fuel that has been "cooled" for as little as 180 days. Because this material is still extremely radioactive, much of the material weight of existing casks is dedicated to shielding rather than payload. As a result, existing casks have relatively low payloads. For example, a typical legal-weight truck cask can carry only one pressurized-water-reactor (PWR) or two boiling-water-reactor (BWR) assemblies.

OCRWM has initiated a two-phase cask program. The near-term phase involves procuring new casks based on current proven technology, while the longterm phase concentrates on improving the efficiency of shipments by developing high-capacity casks. Given the fact that spent fuel to be transported under the NWPA program will be cooled a minimum of five years - and, therefore, will have lost much of its radioactivity - "new generation" casks will have lower shielding requirements. Because greater capacity translates into fewer trips, both operating costs and the overali risk of accidents may be reduced.

The first initiative of DOE's cask development program is the develepment of from-reactor casks. This step is currently underway, with DOE's ldaho Operations office responsible for developing protetrpe casks. Iaving solicited and received designs from private contractors, DCit now comcentrating its efforts on 
developing one new cask for truck shipments and one for rail or barge shipments. A second design for these different modes is being developed at a lower level of prierity. Once the design of from-ractor casks has been completed, DOE will focus on developing casks for transporting spent fuel from the MRS facility to the repository and for transporting material that comnot be acommodated by existing or mew designs. DOE is currenty considering whether to researsh entirely new design for these casks or to modify desions developed under the first initiative.

Betore a design can be used to fabricate shipping casks, it must meet performance standards, testing conditions and cortification requirements established by the NRC. To obtain NRC certification (which must be renewed exery five years), DOE must atemonstrate that casks will be able to withstand the following conditions:

Normal Conditions

- Hot (100) F) and cold $(-40 \mathrm{~F})$ environments.

- External presisure changes from $3.5 \mathrm{lb}$. in. to $20 \mathrm{lb} . / \mathrm{in}$.

- Normal ribration experienced during transportation.

- Simulated rainfall of two inches per hour for one hour.

- Free fall from one to four lecet depending on the package weight.

- Water immersion-compression tests.

- Impact of a 13-1b. steel cylinder with rounded ends dropped from 40 inches onto the most vulnerable surface.

Accident Conditions

- Freedrop from 30feet onto an unyielding surface in a way most likely to cause damage to the cask.

- Free drop from t() inches onto the end of a six-inch-diameter vertical steel bar.

- Exposure for not less than 30 minutes to temperatures of $1,475 \mathrm{~F}$.

- Immersion in at least three feet of water for eight hours in an orientation most likely to result in leakage.

The NRC also has specific regulations pertaining to the release of radioactive particles under normal conditions and under hypothetical accident eonditions. Based on cask compliance with NRC regulations and on data for non-radiological transportation accidents, 10 ) E estimates that one accident in every 80 million shipment miles mould cause cask damage resulting in a radiological harard slightly above NRC limits. 
One concern that has been raised by observers of the Civilian Radioactive Waste Management Program is the mamer by which cask designs are to be tested for certification. Rather than putting prototype models through the aforementioned tests, the NRC requires only that scale models perform up to its standards. Various groups, including several state organizations, have asked DOE to submit full-scale casks for testing rather than scale models. Despite the high level of interest in fullscale testing, OCRIVM has consistently refused to adopt this procedure as a politically popular, albeit technically unnecessary, safety measure.

The nuclear power industry has expressed reservations about the scope and pace of OCRWM's cask development program. Specifically, with the proposed start-up date for the repository and the MRS facility far in the future (and possibly receding), utilities are concerned that if OCRWM proceeds with cask development at too rapid a pace, it will fail to consider the possible effects that increased spentfuel burnup and changes in regulatory repuirements may have on cask design. Perhaps most importantly from the perspective of utilities, if spent-fuel assemblies in temporary dry storage require repackaging prior to shipping, the costs (and, to a lesser extent, the risks) associated with repackaging this material could become substantial by the time the program begins.

The GAO recently assessed DOE's cask development program and recommended three modifications based on concerns expressed by the utility industry. First, cask designs should take into consideration nuclear industry experience with transportation of spent fuel, in addition to incorporating the final results of DOE's study of facility interface capabilities. The GAO also suggested that the Secretary of Energy assess the potential effects increased on-site storage capacity might have on the cask development program; that is, delays in the construction of an MRS facility might force utilities to expand their on-site storage capacity which, in turn, would reduce or entirely eliminate the need for monitored retrievable storage. Should this situation arise, cask development and procurement could be postponed until as late as five years prior to operation of the repository, or 2005. Lastly, the CAO advised DOE to determine whether the combined weight of the loaded cask, tractor and trailer would meet legal-weight limits for truck shipments and, if not, to develop ways of reducing the weight.

\section{Oprontions Program}

The operations program consists of five subsystems. Under the Transporfitin Cask subsystem, DOE will be involved in designing and testing from-reactor a.aks from . In operations perspective, such as ways to design casks so as to reduce handling time and worker exposure. The Siricing and Maintemance subsystem covers the task of developing cask and vehicle maintenance capability. Included

\section{2 - High-Level Radioactive Waste}


under this subsystem is the construction of a maintenance facility for storing equipment, conducting repairs, and decontaminating, maintaining or reconfiguring casks, among other activities.

Performance criteria for legal-weight cask transport vehicles are determined within the Carringe subsystem. DOE currently estimates a 1,000-pound margin between the total weight of trucks loaded with legal-weight casks and the 80,00()-pound weight limit on the Interstate Highway System. Under the carriage subsystem, DOE will work to identify ways to increase this margin to accommodate state concerns, while at the same time maintaining the overall safety of transportation. Other activities under this subsystem include driver qualifications and training, developing operating procedures, and in-transit security and communications equipment. A system of shipment-tracking via satellite (TRANSCOM) will be tested during dry-run shipments of transuranic waste to the Waste Isolation Pilot Plant. If successful, this system may be used to track NWPA shipments.

DOE's responsibilities under the Planning and Control subsystem include ensuring that the transportation program adheres to federal, state and local transportation regulations. In addition, DOE must carefully plan and manage its shipping campaign, including the spent fuel management practices of utilities. Having agreed to accept spent fuel from utilities signing Standard Disposal Contracts, DOE annually issues an acceptance priority ranking based on a policy of "oldest fuel first." The name of the policy implies that the oldest fuel will literally be the first accepted for shipment; however, in practice, utilities who own the oldest fuel hold the rights to first shipment and are not required to start with their oldest fuel. Furthermore, with DOE approval, utilities may trade rankings. DOE is currently assessing the implications of Standard Disposal Contracts and the "oldest fuel first" policy for shipment planning.

Lastly, the Field Operations subsystem requires DOE to devise specific plans for interaction between the transportation system and each reactor site. These plans will contain information regarding cask handling capabilities, special equipment needs, training needs and pickup schedules. As part of this subsystem, DOE conducted a Facility-Interface Capability Assessment, which identifies physical constraints on cask receiving, loading and shipping at the 76 reactor sites from which DOE is obligated to accept spent fuel. DOE's Near-Site Transportation Infrastructure study evaluates the sites on the basis of accessibility via truck, rail and harge transportation. These two studies will be instrumental in preparing schedules for spent-fuel shipments. 


\section{Transportation Institutional Plan}

As with the dispossl program itself, the transportation system must strike some sort of balance between physical, economic and political reality. The focus of the TII' is to resolve issues surrounding the transportation of spent fuel and highlevel waste with affected parties at the state and local levels. A number of issues have been identified regarding the development and implementation of DOE's transportation program.

\section{Moital Mix}

To date, rail and truck transport have comprised the primary modes for shipping high-level waste, accounting for $51 \%$ and $43 \%$, respectively, of shipments already completed. Other available options include barge, overweight truck and rail shipments, and intermodal shipments in which cargo is transferred from one mode to another.

During the first 12 years of MRS operation, DOE plans to accept less than 1000 metric tons of uranium (MTUs) annually. The amount of waste accepted for storage will increase to 3000 MTUs annually in 2015. According to one report, transporting 3000) MTUs of spent fuel annually to an MRS facility will require approximately 100 truck shipments and 10 train shipments per month. This rough estimate, though, will need to be refined as decisions are made concerning the payload of shipping casks.

In deciding the appropriate mix of transportation modes for the Civilian Radioactive Waste Management Program, DOE will consider a variety of factors: safety, efficiency, capital costs, hauling costs, carrier capabilities, facility capabilities and constraints, environmental impacts and overall public acceptance. Under HMTUSA, DOT must determine which factors, if any, should be considered by shippers and carriers in selecting routes and modes that would enhance overall public safety when transporting radioactive waste.

The safety of each mode involves both the inherent safety (i.e., the probability and severity of accidents) and the ability to limit the exposure to the public by using routes that bypass population centers. Capital and hauling costs are another factor, because the ratepayer will ultimately bear the cost of the program. Furthermore, even if safety can be greatly enhanced by initial investment, at some point additional expenditures result in diminishing returns to safety.

In addition to cost and safety factors, the mixture of transportation modes will be based on the quantities of spent fuel accessible by each mode. The Facility- 
Interface Capability Assessment identifies modal constraints at the 122 operating storage facility units across the country. The study found that $46 \%$ of these sites are served primarily by truck and $54 \%$ primarily by ral. The physical condition of both the ralway and highway intrastructures will also be considered in choosing between transportation modes. The modal mix will ultimately bedetermined by the handling capabilities of the utilities. (For further information on highway infrastructure in the Midwest, see CSC-MW's Highadely Mifrastracture Repert.)

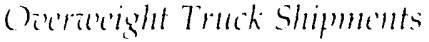

Under the Surface Transportation Assistance Act (STAA) of 1982, states were required to adopt the federal maximum weight limit for interstate highways. Non-interstate highways remain subject to state-set weight limits. STAA places a limit of $8(0,0)(0$ pounds on gross vehicle weight for vehicles traveling on interstates. For shipments under the Civilian Radioactive Waste Management Program, however, DOE is exploring the possibility of exceeding these limits, becouse the use of overweight trucks would reduce the total number of shipments. All states except Ceorgia are capable of accommodating truck shipments of up to 115,000 pounds, depending on the dimensions of the truck and trailer and on the configuration of the axles.

Among the issues surrounding DOE's choice of overweight shipments is the potential damage to the transportation infrastructure. States contend that because bridges and highways were built to accommodate certain stresses and weights, the existing infrastructure will require maintenance and reconstruction in excess of what would be necessary given normal usige. On the other hand, the federal government cites studies conducted by the American Association of State Highway and Transportation Officials ( $\triangle A$ SHITO) to support its contention that (orerweight truck shipments of radioactive material will not damage the highway infrastructure. For example, overweight shipments of a varicty of materials occur on a regular basis, with overweight trucks carrying radioactive cargo responsible for only a small portion of the damage incurred by highways and bridges. In addition, the gains to the infrastructure from having to endure fewer shipments have the potential to more than offset any damage caused by overweight trucks.

Another obstacle in the way of overi eight truck shipments is the matter of state permitting. States reserve the right to approve of overweight truck shipments that pass through their jurisdictions. For the federal program, this means giving up a significant level of autonomy over shipments: the state permitting authority has the power to specify routes, speeds, times of travel, fees, liability, escort requirements and inspections of overweight shipments. Moreover, some states have timeof-day and seasonal restrictions on overweight truck travel. All these factors - plus 
the added complication of states having different procedures and requirements for overweight travel - ma inhibit DOE's ability to use overweight trucks for NWPA shipments. Under the auspices of DOE, an A ASHTO working group has developed a uniform permitting procedure and form for overweight shipments that states may use to standardize their procedures.

\section{Highony Routing}

The costs and risks associated with rail and truck transportation largely depend on the routes over which shipments travel. In 1982, DOT adopted regulations pertaining to the highway routing of "large quantities" (redefined in 1983 as "highway route controlled quantities") of radioactive materials, including spent fuel and high-level waste. Referred to as HM-164 (the docket number assigned to the rulemaking proceeding), these regulations apply to spent-fuel shipments under the Civilian Radioactive Waste Management Program. One requirement of 1 IM-164 is that motor carriers use preferred highway routes. These routes follow the Interstate Highway System including by passes around cities where available. State and tribal governments may identify alternative routes; however, to be accepted, these routes must reduce the risk to the public of transporting radioactive waste and should have adequate fuel and repair shops to meet the needs of heavy trucks.

States and tribes are encouraged, but not required, to examine the highway systems within their jurisdictions to determine which routes can be used to supplement the Interstate Highway System. Affected local governments are not explicitly barred from the routing process, but DOT considers states to be in a better position to work toward the goal of a uniform system of national highway routes.

To date, eight states (Arkansas, Colorado, Iowa, Kentucky, Nebraska, New Mexico, Tennessee and Virginia) have designated alternative routes. These states indicate that identification of a definitive routing authority facilitates the routing process. DOT routing regulations identify that agency authorized to use state legal processes to impose enforceable routing requirements on carriers of radioactive materials as the proper state routing authority. In many Midwestern states lacking this type of agency, routing responsibilities are held by agencies with general grants of authority todevise rules and regulations pertaining to hazardous and radioactive materials. Whether or not the se agencies satisfy the federal definition of a state routing authority remains unclear. Routes designated by such agencies may be subject to legal challenges. (For further information, see CSG-MW's Midzoestern State's Highway Routing Report.)

When comparing alternative routes, the normal radiation exposure during transit and the public health and property risks from an accidental release of 
radioactive materials are the primary factors to consider. DOT routing guidelines (enumerated in Guidelines for Selecting Preferred Highway Route's for Highany Route' Comtrolled (anantity Shipments of Ratioactio' Materials) direct routing authorities to consider accident frequencies (accidents per vehicle mile), traffic volume, average vehicle speed, population distribution along the route and land use data for each route under consideration. Secondary factors that determine risk include emergency response and evacuation capabilities along the routes and the location of special facilities such as schools and hospitals.

\section{Rail Routing}

Under the Hazardous Materials Transportation Act, DOT has explicit authority to promulgate routing regulations for any transportation mode; however, it has not issued any regulations for rail routing analogous to HM-164. Should DOT fail to issue such regulations, DOE will devise its own route-planning criteria for rail shipments of radioactive waste. The previous lack of federal action in this regard stems in part from the fact that, while the various levels of government can easily be brought into the routing process concerning public roads, rail rights-of-way are privately owned, thus effectively restricting the regulatory activities of state, tribal and local governments. As a result, units of government below the federal level will have only limited input into routing rail shipments of spent fuel.

Routing shipments via rail faces two primary constraints. First, there are fewer track miles than highway miles, thus the number of possible routes is limited. Secondly, the poor condition of many tracks further reduces the number of alternative routes available for shipping high-level waste. Rail companies may choose to deny rival companies access to rail lines for NWPA shipments because commercial shipments are generally more profitable and because of the potential difficulties associated with rerouting commercial traffic in the event of an accident involving radioactive material.

A 1982 Federal Railroad Administration study found that distance traveled has the greatest impact on both risk and cost of rail shipments. The greatest reduction in risk can be achieved by avoiding areas of population. Unlike the Interstate Highway System, though, rail lines generally do not have bypasses around major cities. The study concluded the routing of shipments around population centers could reduce the total population exposure by as much as $25 \%$. Such a policy, however, would increase the distance traveled and the need for handling, because shipments would need to be transferred between rail companies. In addition to increasing the cost of shipments, the increase in handling and distance traveled would negate the risk reduction brought about by a policy of population avoidance. 
HMTUSA requires DOT to produce several reports that may affect the transportation of radioactive waste under the Civilian Radionctive Waste Management Program. Among these is a study to determine which factors, if any, shippers and carriers should conside: when choseing among transportation modes and when selecting routes for shipping radionctis: waste. Additionally, DOT must compare the advantages of using dedicated and general-commerce trains for transporting spent fuel and high-level waste.

\section{Safoguanting Shipments}

The NRC has the authority to regulate the physical security of spent-fuel shipments. HM-104 routing regulations require adherence to NRC procedures for the physical protection of these shipments against theft or acts of sabotage. Among the NRC repuirements are:

- Advance NRC approval of routes.

- Procedures to cope with theft or sabotage of shipments.

- Visual surveillance of shipments during stops.

- Use of a written shipment log.

- Avoiding intermediate stops as much as possible.

- A communication center to monitor the shipment.

- Calls to the center by escorts at least every two hours.

- Twoor more armed escoris through heavily populated areas.

- Adrance arrangements with local law-enforcement officials along routes to assist in emergency response activities.

Most of these requirements, originally published in 1979, were based on risk estimates that -.. due to lack of data at the time - were subject to large uncertainties. Later analyses produced significantly lower estimates of risk. As a consequence, in 1984 the NRC proposed eliminating certain requirements for shipments of spent fuel that has cooled for 150 days or more. Still awaiting final disposition, the proposed amendments would eliminate the requirements for maintenance of a communication center, written logs, advance arrangements with local officials, armed escorts and advance route approval by the NRC.

\section{Prenotification}

According to NRC regulations, the governor of a state (or the governor's designee) must receive written notification from shippers before radioactive waste is transported through or within a state. Notification through the mail must be postmarked at least seven days prior to the shipment entering or moving within the

\section{8 - High-Level Radioactive Waste}


state. Advance notice of at least four days is required if notification is delivered by me'ssenger. Any subsequent changes of more than six hours in the shipment schedule must be reported to the governor or to his or her designee.

For all modes of tronsportation, prior notification must be provided to all affected states. The question of whether or not DOE will prenotify Native American tribes regarding NWI'A shipments has not vet been decided. For highway shipments, route plans filed by the motor carrier with the shipper serve as the basis of information needed to satisty the prenotification requirement. The information necessary in prenotification of shipments of any transportation mode includes:

- Name, address and telephone number of the shipper, carrier and receiver.

- A description of the shipment.

- A listing of the route's to be used within the state.

- The estimated time and date of departure from the point of shipping origin.

- A statement that the shipping information must be withheld from the public for least 10 days after the shipment.

Prenotification is an important procedure that provides states with sufficient time to prepare their emergency response systems for potential accidents. Furthermore, lead time is necessary to help officials arrange shipment escorts and to plan inspection and enforcement activities. Final prenotification procedures for high-level waste and spent-fuel shipments will be developed by the time DOE solicits requests for proposals from prospective transportation service contractors.

The written prenotification system mav eventually be augmented by a satellite tracking system such as the TRANSCOM system tested under the Waste lsolation Pilot Plant (WIPP) program in New Mexico. This system allows state officials to track shipments at all times, presumably increasing security and helping to expedite emergency response activities when required.

\section{Transportation Intrastructure}

The condition of the transportation infrastructure over which spent fuel and high-level waste will be shipped affects both the safety and efficiency of these shipments as well as the selection of modes and specific routes. The NWPA provides for financial and technical assistance to mitigate the impact of federal facilities on host areas, but there are no guidelines for using the NWF to improve the transportation infrastructure in these areas. DOF initiated the Near-Site 
Transportation Infrastructure Study to determine the condition of the roads, rail tracks and bridges connecting reactor sites to main-line transportation routes. The study will also provide information on the extent to which highways will be able to accommodate overweight truck shipments.

\section{Inspection and Enforcencent}

Federal and state regulations designed to minimize the risk and cost of transporting spent fuel and high-level waste depend on an effective system of inspection and enforcement. These activities must be directed at all segments of the radioactive waste transportation program, from cask development and handling procedures to routing and driver safety.

Inspection and enforcement activities at the federal level are distributed between the NRC and DOT. The NRC is responsible for inspecting transportation casks and may also perform quality-assurance inspections during cask fabrication. In addition, the NRC can inspect its licensees' procedures for preparing, loading and maintaining casks, and for physical protection and radiation monitoring. DOT inspections are designed to ensure compliance with regulations for package marking and labeling, placarding, shipping papers, radiation emissions, routing and driver training. DO'T also inspects track safety, operating practices, power and equipment, and signal and train controls for rail shipments. DOE exercises much the same authority over detense-related shipments, with penalties for non-compliance specified in written agreements with its contractors.

States that want to take responsibility for inspection and enforcement activities must adopt federal regulations into their state codes and tailor their programs to comply with federal standards. Mlinois is one state that has become involved in enforcing regulation of radioactive materials transportation. It has an extensive inspection and enforcement system supported by fees charged for each cask of radioactive waste originating in or traveling through the state. This type of fee system is allowed under HMTUSA as long as the fees are equitably assessed and are used for purposes involving the transportation of hazardous materials.

Although the federal government does not interfere in the setting of rates for state-levied fees, HMTUSA directs DOT to determine whether or not states should restrict the collection of fees to indigenous motor carriers. The imposition of such a restriction will inevitably create tension between the political desire to keep fees low and the fiscal need to raise in-state shipment fees to maintain emergency response and enforcement funds. An additional complication for states is that the federal government may be able to reduce the federal financial assistance

\section{0 - High-Level Radioactive Waste}


wailable to state's under Section 180(c) of the NWI'A by an amount equal to the fees collected by each state.

IMTUSA also contains provisions designed to promote uniformity among state inspection and enforcement activities. A working group of state and local gevernment officials has been directed to standardize paperwork and procectures for registering haulers of hazardous materials, including radioactive materials. Furthermore, in 1986, DOE and the Commercial Vehicle Safety Alliance (CVSA) renewed theircouperative agreement to develop uniform and reciprocal inspection and enforcement procedures among states for NWPA shipments. As part of the original agreement, recommendations on driver, vehicle and package inspections were developed, including a recommendation to minimize or eliminate en route inspections. Linder the renewal agreement, DOE and CVSA will conduct a pilot study of the recommended inspection procedures applied to shipments of radioactive material to the WIPP' facility and other major shipping campaigns as they are intablished.

Lastiy, HMTUSA adds 10 inspectors to the federal inspection force to promote safety in the transportation of radioactive materials. The Secretary of Transportation may also authorize "self-certification" of vehicles providing the inspector used meets certain federal requirements.

\section{Acintent Ripurting}

Immediately after an incident has occurred during transportation involvins hazardous materials (including handling and temporary storage while in transit), federal regulations reyuire the carrier to notify the shipper and DOT if the incident results in:

- The death of a person.

- Persomal injuries requiring hospitalization.

- Fistimated property damage in excess of $\$ 50,000$.

- The evacuation of the general public lasting one hour or more.

- The closing of one or more major transportation arteries or facilities for one hour or more.

- Potential contamination, if radionctive maternals are involved.

- Potential release of disease-causing agents that are dangerous to life or property.

Within 15 das of the initial report, a written report of the accident must be usbmitted. State and local onficials are also notified immediately se that they may take action ter protect the health and safety of the public. 
First-response activities during a transportation accictent areconducted by state, tribal and local gowermments, with assistance from the federal govermment provided only on repuent. Although local persommel are often the first agents to respond to an aceident, the state govermment is responsible for emergency planning, preparedness and response, and courdination and control of radiological emergencies. States are specifically respensible for:

- Developing a ratiological emergency response plan that designates responsibilities and resources for planning, preparedness and respomse.

- Designating emergency response teams made up of individuals with appropriate ratiological emergency expertise.

- Coordinating a system of communication between state agencies, the federal gowernment, locill response persomed and the public.

- Negotiating agrements with neighboring states and tribes regarding response to accidents near a common border.

- Ensuring that appropriate persomel are trained to perform their respective tasks in acourdance with the emergency response plan.

To assist states with the development of these plans, the Federal Emergency Management Agency (FEMA) has issued two reports. FEMA-REP-I (Revision I) provides information on preparing emergency response plans to deal with the offsite effects of radiological acidents that ocour at nuclear power plants. Before a plant can begin operating, state and local govermments in the vicinity of the plant must receive approval for their emergency response plans.

FEMA-REP-5 provides guidanoe to state and focal govermments in their development of radiological emergency response plans targeted toward transportation accidents. Several states in the Midwest have developed such plans which, as recommended by FEMA, are integrated with basic emergency and disaster response plans. States that do not plan specifically for trar sportation accidents involving radioactive materials, but rather rely on existing emergency response plans, should make sure these plans are sufficient to deal with radiological accidents. As lyed approaches, more states may chouse to devise plans specifically for acodents occurring during the tramsport of radionctive materials.

State plans for emergency response direct an emergency services or response agenoy tocoordinate state, local, federal and private resources. In addition 
todesignating the lead agency, a typical state plan identifies other state agencies that are expected to take part in or support on-sene response activities, basing these decisions on the function of each ageney and the nature of the emergency. In most states, the department of public health serves as a primary support agency for radiological emergencies. L pom notification that an accident involving radioative materials has accurred, radiolegical experts, such as halth physicists, are dispatched individually or in teams to the sene of the accident, where they subseyuently measure, analyze and moniter the radiolegical hasad and overese mitigation and clean-up efforts. Thene experts can be empleyed by state or local governments, universities, utilities or the private sector. (For more information on state emergency response and preparedness plans, see ( SC,-MW's Mididestern Radiologi-

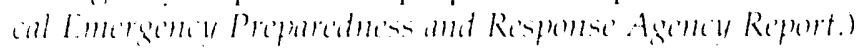

Tramsportation acidents that acur near the border between two states ma! be dealt with by one or both states if a mutual aid agreement (MAA) exists between the states. The'se agrements enable signatories to share or exchange renoures under specific conditions during various emergency situations. MAAs an take the form of interstate compacts, multistate agreements, interjurisdictional decuments or memoranda of understanding.

The oldest MAA among the states that is applicuble to ratiolegicat emergencies is the Interstate (ivil Defense and D)isater (impact, formed in 1450 .

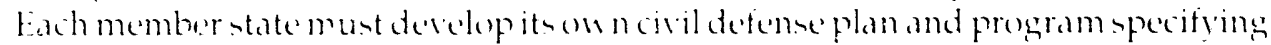
persennel, supplien and eyupment to be uned during emergeney situations. The purpone of the cimpact is lo help staten combat emergencies or disasters, with refuents for ad by one state being met by other members. Although this compact was net intended specifically for emergeney response in cases of radionative waste transportation acdedents, the training and eywipment derived from it are very unetul fordeding with such emerancion.

Lnlike state in the Dortheant and the South, Midwestern staten have not vet sormed an MA A . More intormal or geographically limited aid agreements do eist, hemerer. An example in the Midwent in the memorandum of understanding between the Nebrank State (ivil Defence Agency and the Misoneri State Emer-

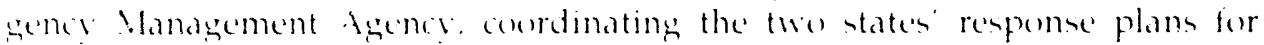

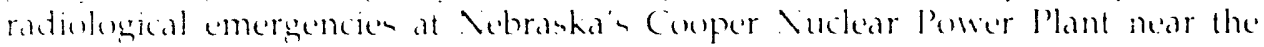

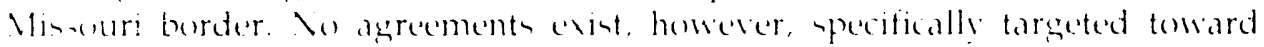
tranpportation accidente insolving spent fued and high-level waste. Furthermore,

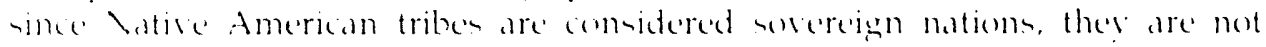

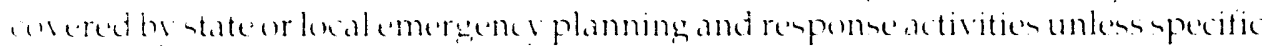

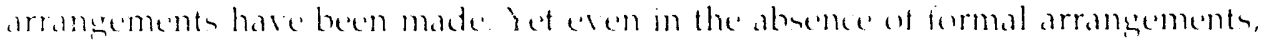

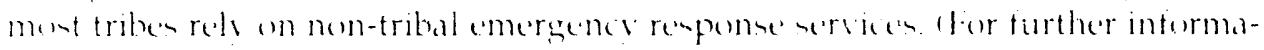


tion on MAAs and on interstate agreements in the Midwest, see CSG-MW's Report on Mutual Aid Agrements for Ratiological Transportation Emergencies and Model State' Mutual Aid Agre'me'nt.)

State officials can also call upon utilities for assistance during transportation emergencies involving radioactive cargo. Because federal law requires utilities to develop and receive approval for plans to deal with radiological emergencies at nuclear power stations, most utilities are well equipped to lend technical support to state and local government agents responding to transportation accidents. Under a voluntary agreement within the industry, a utility near the seene of an accident will respond on behalf of the utility shipping the material; however, since DOE will be the shipper of record for NWPA shipments, this agreement will not necessarily be activated.

If a state camnot respond adequately to a radiological emergency with either its own resounces or those available through an assistance agreement, the state's lead emergency response agency can request assistance from the federal government. The Federal Radiological Emergency Response Plan (FRERP) outlines the federal government's response plan for all types of radiological emergencies, including transportation accidents. FRERP is primarily directed at coordinating federal support of state and local efforts to cope with emergencies at nuclear power plants or other fixed facilities.

FEMA is the lead agency for all types of emergencies and disasters, with DOE and the Envirommental Protection Agency (EPA) playing key support roles for radiological emergencies. FRERP would be implemented most often during major radiological emergencies; in more limited emergency situations, the Federal Radiological Monitoring and Assessment Plan (FRMAP, Section III of FRERI') can be implemented as a separate respense plan. Under FRMAI', DOE is responsible for coordinating federal radiologrical monitoring and assessment assistance for state and local gowermments during the initial phase of an emergency, with EPA taking over this role in subseyuent stages.

To meet its responsibilities under FRMAP, DOE maintains an emergency response program in eight Regional Coordinating Offices (RCOs) throughout the United States. Depending upen the nature and magnitude of the emergency, the response from $R C($ s can range from providing advice over the phome to activating FRMAP or FRERI'

Citing the "fragmented and duplicative" nature of its transportation emergency response capabilities, DOE recently initiated a program to bring these activities fogether under one coordinated program. The goals of the Transportation 
Emergency P'reparedness Program (TEPP) are to ensure DOE's ability to respond to transportation incidents involving DOE shipments and also to make sure DOE can meet its obligation to provide technical advice and assistance in the event of transportation emergencie's involving radioactive or mixed hazardous waste. Specific TEPP initiatives include developing a training and exercise program for transportation emergency response activities and a program for verifying the procedures of individual programs. A TEPl' Steering Committee will coordinate transportation emergency preparedness activities and develop strategies for improving response capabilities throughout DOE. TEPl also provides for interaction with and input from state, tribal and local organizations through the establishment of a Transportation External Coordination (TEC) Working Croup.

\section{Tramm!s}

One element of a state's responsibility for emergency preparedness and emergency response is to make certain state and local personnel receive ade puate training to respond effectively to emergencies. Such training has traditionally been subsumed under hazardous materials and civil defense training programs offered by federal, state and local govermments and by industry.

Federal agencies involved in emergency response training include FEMA, EIA, DOT, DOE and the Department of Health and Human Services. Through these agencies, the federal government of fers training courses covering a variety of emergency response-rehated topics. Authority for these federal training activities stems from the (ivil Defense Act (1950); the Atomic Energy Act (1954); IIMTA (1455); the Comprehensive Environmental Response, Compensation and Liability Act (148(1); the Superfund Amendments and Reauthorization Ad (1986); and HIMTLSA (149()). The last piece of legislation consolidated much of the federal gowernment's emergency response training activities, thus oliminating outdated and duplicative coursen and making it easier for states te select the federal training needed to develop the skills of emergency response personnel.

DOF: is responsible for providing technical assistance and funding to states for training safety persomnel of local and tribal governments through whose jurisdictions. VWPA shipments will travel. Authorized under Section 180)(c) of the NWPA, this training must coerer "procedures reyuired for safe routine transportation of lspent fuel and high-level wastel, as well as procedures for dealing with emergency response siturations."

In February 1442, (OCRWM released its draft strategy for implementing 180)(c) training assistance. This decument incorporates comments received on a preliminary draft completed in November 199(). In both drafts, D) Fe recognized the 
need to address a variety of issues before beginning training assistance. The most important of these issues for states are the scope and definition of assistance (particularly as related to "safe routine transportation"), the timing of assistance, and funding and assistance mechanisms. With regard to funding mechanisms, it has been suggested that $180(0)$ training funds should be channelled directly to states rather than having them pass them through DOE or its contractors. D()E, however, objects to this type of arrangement, believing that if $180(6)$ assistance is not coordinated at the federal level, the overall radioactive waste transportation training effort will be compromised. States, on the other hand, complain that the existing system is already mired in confusion due to lack of coordination and cooperation among federal agencies.

The timing of assistance is another important issue for states. DOE plans to determine which states and tribal governments will be eligible for training assistance and funding once an MRS site has been identified. According to (OCRWM, its policy will seek to be flexible to allow a ffected governments to determine their own training needs. Because training will take time, and because first responders have a 25 to $30 \%$ annual turnover rate (due to heavy reliance on volunteers), OCRWM's strategy must include a commitment to ensuring the proper timing of training assistance. (For further information on training programs and assistance, see CSCMW's Rationatio' Materials Transportation Saferty Training Repurt and Timing and Funding of Emergency Respense Training in Midide'stern Stute's.)

\section{Liability}

Liability coverage extends to damages incurred by the public as a result of either a general transportation accident or a radiological incident. In the event of a traffic accident that does inet involve any release of radioactive materials, liability for personal injury and property damages would be determined according to the law of the appropriate state, most often the state in which the accident ocrurred. The Motor Carrier Act of 1980 reguires motor carriers of hazardous waste to have at least 55 million worth of insurance for each vehicle operated by carriersof spent fuel and high-level waste in either intra- or interstate commerce. Rail carriers of hazardeus materials are not required by federal law to carrv a minimum amount of financial protection, but many companies protect themselves through either selfinsurance or commercial corerage.

Liability coverage under the Price-Anderson Act of 1957 applies to "nuclear incidents" that accur during transport of radiodetive material to or from certain federally licensed or federal contractor-operated facilities. A "nuclear incident" is defined as "any oceurrence ... within or outside the United States, causing bodily" injury, sickness, disedate, or death, or loss of or damage to property, or loss of or use

\section{6 - High-Level Radioactive Waste}


of property, arising out of or resulting from the radioactive, toxic, explosive, or other hazardous properties" of materials such as spent fuel and high-level waste. State law's still apply to the determination of liability and damages, but the PriceAnderson system of insurance covers the payment of those damages.

The first tier of the Price-Anderson system is private insurance coverage. All operators of NRC-licensed nuclear power plants must obtain private coverage for liability, with utilities operating large power plants (those with capacity greater than $10(1)$ MWe required to obtain the maximum amount of insurance coverage avilable, currently $\$ 2(6)$ million. Coverage for large plants is supplemented by "industry retrospective premiums." This second layer of protection provides that, in the erent of a nuclear incident, operators of large nuclear power plants pay a prorated share of the exeess damages, each plant being liable for up to $\$ 6.3$ milliom per incident, with a moximum annual assessment of $\$ 10$ million. The total amount of liability coverage currently available under the Price-Anderson system is just over 57 billion. Lnder the 1988 reauthorization of the Price-Andersen Act, total liability is limited to $\$ 7.2$ billion. The act authorizes Congress to pay damages in excess of this amount if such action is found to be necessary and appropriate.

The federal government indemnifies DOE contractors, govermment licensees and non-profit educational institutions from liability for certain activities. The level of indemnification is based on the amount of financial protection required of large power reactors under the Price-Anderson system. As a consequence, indemnity increases as more plants are licensed to operate, with a lower limit of $\$ 7.067$ billion. As provided in the amendments to the Price-Anderson Act, nuclear waste activities - including transportation - are indemnified to the same level of protection avalable to $\mathrm{DOE}$ contractors. Payments for damages arising from indemnified actirities would be charged to the NWF.

The Prico-Anderson system covers damages incurred as a result of acts of sabotage or terrorism, provided the responsibility for the materia' involved can be traced to a particular source, swe as the federal govermment. In the event that damages are caused by radioative material that has been diverted from normal transportation and the material ammot be traced to a particular source, PriceAnderson coverage does not apply. In such an instance, Congress would be authorized to review the incident and provide apprepriate compensation.

Price-Anderson coverage applies to precautionary evacuations conducted in response to nuclear incidents. DOF comsiders accident-related cleanup costs and activities (e.g., decontamination, monitoring) to be rembursable. In addition, the Price-Andersom Amendments Act provides compensation to state and local gorcrmments for costs associated with omergency response to transportation accidents. 
Standard tort defense's are arailable to potentially respomsible parties in all cases except these that involve an "extraordinary muclear oceurrenee" (ENO)), defined as an incident that results in substantial off-site damage to persons (Ir property. In the event the NRC dechares an incident to be an ENO), various defenses are waived, including contributery negligence, government immunity and cortain state-imposed statutes of limitationsts.

\section{State. Tribal and Locol Regulation of Thansportation}

Although the federal govermment is responsible for the bulk of rules and regulations concerning radioactive waste management and transportation, state., tribal and local governments have some authority over shipments of radioactive material that originate in or pass through their jurisdictions. For the most part, these regulations duplicate or supplement federal regulations. In situations where state, tribal or lecal regulations conflict or are inconsistent with federal regulations, the latter generally take precedence.

INTA authorized IXOT to establish procedures for determining whether stateor focal reguirements conflict with federal hazardous materials transportation regulations. Under this rule, parties affected by state or local regulations can petition D()T to judge whether particular measures are consistent with federal regulations. HIMTLSA expanded DOT's authority, making the department's judgment binding unless it is overturned in federal court. In issuing rulings, I) considers whether compriance with both the state or local regulation and federal laws is possible and the extent to which a state or local regulation obstructs the excoution of federal regulations.

The state or lecal requirement is preempted if it fails either the "dual compliance" or the "obstacle" test. Within 30 days of an inconsistency ruling, state or local governments may seek a waiver of federal preenption or challenge Dol" ruling. DOT may isste waivers of preemption if the regulation in epestion in "subatantively the same as" federal rules - that is, if it affords a level of safety a high as or higher thom that provided for in federal regulations, yed dees not place an unreasomable burden on interstate commerese. If state ar local gorermments are unsuccessful in their attempts to appeal a ruling, they may resort tor hallenging the ruling in fecteral court.

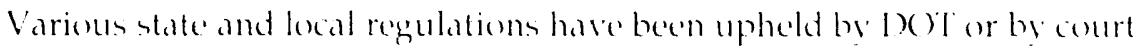
rulings. In (olorado, however, a circuit court ruling recently presmpted cortain state regulations on hasardous materials tramsportation baned on the grounds that the regulations were not "substantively the same as similar federal reguhatioms.

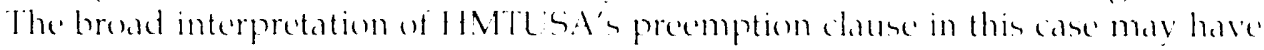

\section{8 - High-Level Radioactive Waste}


significant impelcations for state regulations that attempt to go beyond the requirements of federal laws. To continue to exercise authority over the transportation of spent fuel and high-level radionctive waste, state and local governments must be aware of and understand the basis for DOT inconsistency rules. Once it is released, DOF's comprehensive transportation plan will serve as a resource to further this understanding by outlining DOT and court rulings on federal preemption of regulations. 


\section{Appendix A. Selected Federal and State Laws and Regulations Related to Radioactive Materials Transportation ${ }^{\star}$}

\section{Federal}

Atomic Energy Act (1946, amended in 1954) (42 USC secs. 2011-2296́)

Insurance-liability

Regulations

Interstate Commerce Act (1887 and amendments) (49 USC secs. 10101 et seq.)

Permits (carrier permit)

Transportation operations

Regulations

Federal Railroad Safety Act (1970) (45 USC secs. 421-441)

Inspection and enforcement (regulations-requirements, responsibilities and capabilities, financial support)

Infrastructure improvements (rail conditions)

Regulations

Hazardous Materials Transportation Act (1975), as amended by the Hazardous Materials Transportation Uniform Safety Act (1990) (49 USC secs. 1801-

1812)

Driver-operator training

Inspection and enforcement

Transportation operations

Regulations

Emergency response (financial support)

Insurance

Solid Waste Disposal Act, as amended by the Resource Conservation and

Recovery Act (1976) (42 USC 6901 et seq.)

Inspection and enforcement

Incident notification (methods, timing, responsibility)

Transportation operations

Regulations (adoption of federal regulations)

\footnotetext{
*Adapted from Battelle Nuclear Systems Group, Compendium of Federal and State Radionctio' Materials Transportation Lates and Regulations: Transportation Legislatize Databasc (TLDB), BMI/OTSP-08.
} 
Surface Transportation Assistance Act ri 1982 (49 USC secs. 2301 et sey.)

Inspection and enforcement (regulations-requirements)

Tramsportation operations

Regulations (adoption of federal regulations)

Nuclear Waste Policy Act (1982), as amended by the Nuclear Waste Policy

Amendments Act (1987) (42 USC se's. 101(il et seq.)

Shipment notification (prenotification)

Emergency response (planning and training, financial support)

Cask design and testing (licensing)

Infrastructure improvements (highway conditions)

Transportation operetions

Regulations

Motor Carrier Safety Act (1984) (49 USC secs. 2501 et sec.)

Driver-operator training (regulations-requirements, qualifications)

Inspection and enforcement (regulations-repuirements, responsibilities and (apabilitie's)

Transportation operations

Regulations (consistency with federal regulations)

Commercial Motor V'ehicle Safety Act (1986) (49 USC secs 2701 et seq.)

Driver-operator training (regulations-requirements, qualifications, training, financial support)

Regulations

\section{Illinois}

Illinois Hazardous Materials Transportation Act (Ill. Ann. Stat. ch. 95-1/2, secs.

$7(0)-1$ et sey.)

Inspection and enforcement

Regulations (adoption of federal regulations)

Illinos: Hazardous Materials Law (unofficial) (Ill. Ann. Stat. ch. 127 secs. 1252 et seq.) Emergency response

Incident notification

Transportation operations

Regulations (adoption of federal regulations)

Illinois Nuclear Safety Preparedness Act (Ill. Ann. Stat. ch. 111-1/2, sec. 4304(7))

Fees (per cask for spent-fuel shipments) 
Illinois Radiation Protection Act (III. Ann. Stat. ch. 111-1/2, secs. 211 et secp.)

lnspection and enforcement

Transportation operations

Regulations

Fees (material licensing fees)

Material licensing (NRC-state regulatory agreement, state radiation protection program feature)

Illinois Commercial Transportation Law (Ill. Ann. Stat. ch. 95 1/2, secs. 18c-1101 et sey.)

Inspection and enforcement (regulations-reyuirements, responsibilities and capabilities)

Regulations (adoption of federal regulations, consistency with federal regulations)

Illinois Nuclear Facility Safety Act (III. Ann. Stat. ch. 111-1/2, secs. 1025A-6 et sec.)

Emergency response (financial support)

Inspection and enforcement

\section{Indiana}

Indiana Motor Carrier Act (Ind. Code Ann. secs. 8-2-7-1 et seq.)

Routing (motor vehicle, designation criteria)

Inspection and enforcement

Shipment restrictions

Regulations (adoption of federal regulations)

Feess

Indiana Radiation Control Act (Ind. Code Ann. secs. 13-1-2-1 et seq.)

Inspection and enforcement

Regulations (adoption of federal regulations, consistency with federal regulations)

Fees (material licensing fees)

Materials licensing (NRC-state regulatory agreement, state radiation protection program feature)

\section{lowa}

Motor Carrier Safety Law (unofficial) (lowa Code secs. 321.449-321.450)

Regulations (adoption of federal regulations, consistency with federal regulations)

\section{2 - High-Level Radioactive Waste}


Iowa Radioactive Waste Management Law (unofficial) (lowa Code secs.

455 B. $331-455 B .34(0)$

Emergency Respomse

Permits (transport permit)

Regulations

lowa Transportation Law' (unofficial) (lowa Code sec. 321.266)

Incident notification

Department of Transportation Law' (unofficial) (lowa Code secs. 307.26-307.27)

Inspection and enforcement

Transportation operations

Regulations

Nuclear Transportation Regulations (unofficial) (Iowa Environmental Protection

(ommission Nuclear Materials Transportation Rules, Category 567)

Shipment notification (prenotification)

Regulations

\section{Kansas}

Kansas Transportation Law (unofficial) (Kan. Stat. Ann. sec. 8-1746)

Transportation operations

Regulations

Fmergency Planning Law (unofficial) (Kan. Stat. Ann. sec. 48-901)

Emergency response

Motor Carrier Regulations (unofficial) (Kan. State Corp. Comm., Transp. Div., Regs. 82-4-1 to 82-4-86)

Driver-operator training (qualifications)

Inspection and enforcement

Insurance-liability (insurance requirements and limitations)

Incident notification

Regulations (adoption of federal regulations)

\section{Michigan}

Michigan Radiation Control Act (Mich. Comp. Laws Ann. secs. 333.13501 et seq.)

Inspection and enforcement

Incident notification

Regulations

Materials licensing

Fees 
Fire Prevention Code (unofficial) (Mich. Comp. Law's Ann. secs. 29.1 et sey.) Inspection and enforcement Incident notification Regulations

Radioactive Materials Traisfortation Regulations (unofficial) (Mich. Div. of Radiological tiealth Regs. R325.5801 et sec.; Michigan Fire Safety Board Regs. R29.551 (et sey.)

Routing (motor vehicle, rail, barge, regulations, designation criteria) Emergency response (responsibilities and capabilities, financial support) Inspection and enforcement (regulations-requirements) Incident notification (regulations-requirements, methods, timing, responsibility)

Shipment restrictions Permits (transport permit)

Regulations (adoption of federal regulations)

Michigan Department of Public Health Radiation Protection Regulations (unofficial) (Mich. Dept. of Public Health Rules R325.5001 et seq.)

Fees

Materials licensing

\section{Minnesota}

Mutor Carrier Law (unofficial) (Minn. Stat. Ann. secs. 221.033-221.035)

Driver-operator training

Inspection and enforcement

Insurance-liability

Incident notification

Permits (carrier permit)

Regulations (adoption of federal regulations)

Fees (carrier permit fees)

State Board of Health Law (unofficial) (Minn. Stat. Ann. sec. 144.12(15)

Materials licensing

Minnescota Radioactive Waste Management Law (unofficial) (Minn. Stat. Ann. sec. $116(.731)$

Routing (motor vehicle, designation criteria)

Shipment notification (prenotification)

Emergency response

Inspection and enforcement

Fees 
Hazardous Waste Transportation Regulations (unofficial) (Minn. Dept. of

Transportation Hazardous Waste Transportation Regs. 8870.0100 et seq.)

Driver-operator training

Insurance-liability

Incident notification

Permits (carrier permit)

Fees

\section{Missouri}

Missouri Radiation Control Law (Mo. Rev. Stat. secs. 192.400 et seq.)

Emergency response (responsibilities and capabilities)

Regulations

Materials licensing (NRC-state regulatory agreement, state radiation protection program feature)

Missouri Hazardous Materials Transportation Regulations (Mo. Admin. Code sec. 301.177)

Permits (carrier permit)

Regulations (adoption of federal regulations)

\section{Nebraska}

Nebraska Motor Carrier Act (Neb. Rev. Stat. secs. 75-363 et seq.)

Inspection and enforcement

Insurance-liability

Regulations (adoption of federal regulations)

Nebraska Radiation Control Act (Neb. Rev. Stat. secs. 71-3501 et seq.)

Regulations

Materials licensing (NRC-state regulatory agreement, state radiation protection program feature)

\section{North Dakota}

Materials Licensing Law (unofficial) (N.D. Cent. Code secs. 23-20.1-01 et seq.) Inspection and enforcement

Regulations

Fees (materials licensing fees)

Materials licensing (state radiation protection program feature)

North Dakota Motor Vehicle Act (N.D. Cent. Code Ann. sec. 39-21-44)

Regulations (adoption of federal regulations) 
Radiological Health Rules (N.D. Admin. Code art. 33-10)

Shipment notification (prenotification)

Inspection and enforcement

Transportation operations

Regulations

Fees (materials licensing fees)

Materials licensing (state radiation protection program feature)

Emergency Planning and Community Right-to-Know Act (N.D. Cent. Code Ann. sec. 37-17.1-(17.1)

Emergency response

Fees

\section{Ohio}

Ohio Radiation Protection Law (unofficial) (Ohio Rev. Code Ann. sec. 3701.91) Inspection and enforcement

Regulations (consistency with federal regulations)

Fees (materials licensing fees)

Materials licensing (state radiation protection program feature)

Ohio Atomic Energy Law (unofficial) (Ohio Rev. Code Ann. secs. 4163.01 et sec.)

Routing (motor vehicle, designation criteria)

Shipment notification (prenotification)

Regulations

Hazardous Materials Transportation Act (Ohio Rev. Code Ann. secs. 4905 et seq.)

Routing (motor vehicle, rail, regulations, designation criteria)

Shipment notification (regulations-requirements, prenotification)

Emergency response (planning and training, financial support)

Shipment restrictions

Permits (carrier permit)

Regulations

Fees (carrier permit fees)

Radiation Protection Regulations (unofficial) (Ohio Admin. Code secs. 3701-38-

01 to $37(01-38-39)$

Inspection and enforcement

Regulations (adoption of federal regulations) 


\section{South Dakota}

South Dahota Radiation Resources and Lranium Resources Exposure Control

Act (S.D). Codif. L aws Amm. secs. 34-21-1 et sey.)

Shipment notification (prenotification)

Inspection and enforcement

Incident notification (regulations-requirements, methods, timing, responsibılity)

Regulations (consistency with tederal regulations)

Materials licensing (XRC-state regulatory agreement, state radiation protection program feature)

South Dakota Hazardoun Materials Transportation Safety Act (S.D. Codif. Laws Ann. sec. $49-28 \mathrm{~A}-1$ at secel

Emerigency renponse

Inspection and enforcement

Incident notification

Regulations (adoption of federal regulations)

\section{Wisconsin}

Wincomsin Radiation Protection Act (Wis. Stat. Ann. secs. 140.50 et seq.)

Inspection and enforcement

Reculotions:

feres (materials licensing fees)

Materials licensing (ntate radiation protection program feature)

Wiscomsin Fmergencr Planming Law (unofficial) (Wis. Stat. Ann. secs. 166.01 et secy.)

Emurgency response

Insurance-liability 


\section{Appendix B. Glossary of Terms ${ }^{\star}$}

carrier: Company engag । in transporting high-level waste or spent fuel by land or water.

cask: A large, thick-walled metallic container that provides shielding and physical protection for highly radioactive materials. A cask may hold one or more canisters of consolidated spent-fuel rods, high-level waste or spent-fuel rod assemblies.

chain reaction: The self-sustaining splitting or fissioning of atomic nuclei in the core of a nuclear reactor to release energy. A chain reaction can occur when the nucleus of a uranium or plutonium atom absiorbs a neutron and splits into two smaller atoms, emitting two or more additional neutrons in the process. If these additional neutrons are like'wise absorbed and cause fissioning (see fission), a chain reaction ensues.

commercial naste: Low- and high-level radioactive waste and spent fuel from commercial nuclear power plants, manufacturing industries and institutions (hospitals, universities, research facilities).

contamination: The presence of radioactive material in a previously unaffected environment.

criticality: The point at which a reactor achieves a self-sustaining chain reaction. When a reactor reaches criticality, various technical means are used to control the heat necessary te generate dectricity.

dedicated train: A train purposefully configured and operated to serve a specific function, such as to mose a certain commodity, to use a certain type of equipment or to handle traffic for a certain shipper. Dedicated trains are in contrast to "regular trains," which generally transport larious commodities using different types of equipment for a number of shippers.

defense waste: Rationtive waste resulting from weapons research, the manufacture of nuclear weapons, the reprocessing of defense spent fue! and the operation and decommissioning of nuclear-powered ships and submarines.

*Adapted from (xRHM Trmapurtation Program Referente: Glossary. Acromym List, and Billes'ruphl, I) ()E RW-1)]4?.

38 - High-Level Radioactive Waste 
disposal package: A waste canister containing high-level radioactive waste, spent nuclear fuel or other radioactive materials with an overpack designed for placement in a repository.

fission: The splitting apart of the nucleus of an atom, resulting in the release of large amounts of energy. Fission is usually caused by the absorption of a neutron in a fissionable uranium or plutonium nucleus.

fuel assembly: Typically, a square array of metal rods containing enriched uranium dioxide fuel pellets. Fuel-assembly arrays range from 7 > 7 rods for a boiling-water reactor to $15 \times 15$ rods (some $17 \times 17$ ) for a pressurized water reactor. Fuel for a nuclear power plant is loaded into the reactor core in the form of fuel assemblies (see fuel pellets, fuel rod).

fuel pellets: Small ceramic-like cylindrical units about (1).4 inch in diameter and about 1.5 inch long containing fissionable uranium oxide, the fuel used in a nuclear power plant.

fuel rod: A 12-to 14-fout-long cylindrical unit holding nuclear fuel pellets. The fuel rod is usually made from a zircomium alloy.

high-level radioactive waste: Spent nuclear fuel or the highly radioactive material resulting from the reprocessing of spent nuclear fuel. Other material that the NRC determines by rule or the DOE determines by order, consistent with existing law to require isolation, is also classified as high-level radioactive waste.

highway route controlled quantity: The amount of radioactivity within a certain type of package (see package) that makes it subject to DOT highway routing requirements. As an example, spent nuclear fuel would be a highway route controlled yuantity of radioaction materials.

inconsistency ruling: Decision made by DOT that a state or local regulation is incomsistent with and, hence, preempled by federal regulations. Parties affected by state or local regulations can petition DOT to judge the consistency of the rules. Within 30 days of an inconsistency ruling, state or local governments may seek a waiver of federal preemption or challenge the ruling in federal court.

interim storage: The temporary holding of nuclear waste before final disposal. liamples of interim storage of nuclear waste include spent fuel storage pools at a rexter site or an MRS facility.

ionizing radiation: Fast-particle (alpha and beta particles) and electromagnetic 
waves (gamma rays) emitted from the center (nucleus) of an atom during radioactive disintegration. These particles and rays arecapable of positively charging other atomic nuclei they may encounter by removing negatively charged electrons. Examples of nonionising radiation include light and radio waves.

motor carrier accident: Road accident that results in fatalitien, injuries and property damage of $\$ 25()$ or more, as defined be the Bureau of Notor Carrier Safety, Federal Highway Administration and D) I for ('lases 1 and 11 interstate motor carriers of property. Foderal resulations reyuire reperting of such accidents.

MRS (monitored retrievable storage) facility: A structure to receive spent fucl from commercial nuckear power plants, consolictate and repackage the fued, store it temporarily an reguired and originate the shipment of the waste to a permonent nuclear wiate repository

Nuclear Waste Fund: $A$ fund in the U.S. Treasury, mandated by the NWP'A, composed of fees levied on generators of spent nuclear fuel and high-level nuclear waste to recover all conts associated with the disposal of nuclear waste.

Nuclear Waste Policy Act of 1982 (NWPA): The legislation that provides for the development, licensing, comstruction and operation of geologic repenstories for the dispessal of spent nuclear fuel and high-level radionetive waste. It also establisher a program of resourch, develepment and demonstrations that will support the disposal of nuclear waste.

Nuclear Waste Policy Amendments Act of 1987: The legislation passed by Congress on Decembe: 22, 1987, which amended the NWI'A.

overweight truck: A truck that enceeds the weight limits of a state highway or bridge. Shippers need permission from state transportation offices to operate overweight trucks on public highways.

OCRWM (Office of Civilian Radioactive Waste Management): The office within DOE responsible for implementing the Nuclear Waste Policy Act of 1982.

package: Radioactive material and the pachaging components surrounding it.

preferred route: A highway chosen for the shipment of "highway route controlled quantitien" of radionctive materials usually designated by a state routing agency with routing responsibility. I lowererer, if a state agency does not designate altermative router for radioactive materials transportation, interstate highways within that state are defined as preferred routen by D) D regulations and are accepted routes 
for radionctive materials transportation.

prenotification: Contacting specific affected parties of the planned shipment of radionctive materials. Before transporting spent fuel within or through a state, the VRC repuires the shipper to contact the governor or the governor's designee of that state. D()T regulations reyuire the shipper to make sure each onsignee is aware of the dates of shipment, the expected arrival and any special loading and unlarding instrutions.

Price-Anderson Act: The legislation outlining the methods for compensating muclear power plant or nuclear transportation accident victims. Passed as Subsectiom 17) of the Atomic Energ! Act of 1954, the Price-Anderson Act established a sistem in which a combialion of govermment guarantees and private insurance corerage would pay dams for persomal injury and property damage callsed by nudear aceidents. The legislation limits the liability any one utility must sustain by reyuirmg all nuclear utilities to assist in damage payments should an accident accur. Amerdments in 1965 and 1975 included 10-year extensioms to the Act.

radioactive material (RAM): Any material or combination of maierials that

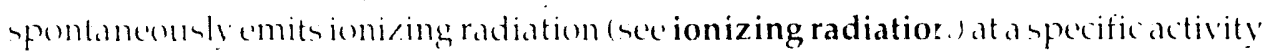
sreater than (1).1) 2 microcuries per gram.

rail routing: The route between the origin and destination of a shipment moving by rail. The route may use the tracks of more than one railroad and may reguire the shipment te move in more than ene train during its trip. There are no specitic rail routing requirements for hazardous materials, but railroads are required to epedite such shipments as much as possible.

repository: Any facility licensed by the NRC for the permanent deep geologic disposal of high-level radionctive waste and spent nuclear fuel. Includes both surface and subsurface areas where high-level radioactive waste and spent nuclear fuel handling activities are conducted.

shipper: The party responsible for the movement of wasteeven though the material may be physically transported by someone else. Under the NWIA, DOE will be respomsible as the shipper for waste shipments to and from NWI'A facilities, while the carrier transporting the waste may be common carriers.

shipping cask: A specially designed container uned for shipping radioactive muterials (nee cask).

shipping papers: Shipping orders, bills of lading, maniteste or other shipping 
documents serving a similar purpose, containing the information required by federal regulations.

spent nuclear fuel: Fuel that has been used in a nuclear power plant s reactor to the point where it no longer contributes efficiently to the mackenr chain reation. Spent fuel is thermally hot and highly radioactive (see chain reaction).

state routing agency: The ageney designated by the state to be responsible for the development of highway routes for the transportation of radionctive materials through that state.

storage cask: Container used for temporary storage of spent nuclear fuel or highlevel nuclear waste at a reactor, interim storage facility or MRS facility (see cask).

transuranic waste (TRU): Waste materials containing nuclides with an atomic number greater than 92 (uranium). It is produced from weapons fabrication and reprocessing of plutonium. 


\section{Midwestern High-Level Radioactive Waste Transportation Project}

\section{Publications}

Midzuestern Radiolegical Lmergency Preparedness and Response Agency Report (May 1990) (DOE/( $1 / / 104(1) 2-2)$

Rationetion Muterials Transportatian Saferty Training Report (May 1990) (DOE/ $\mathrm{CH} / 104(1) 2-3)$

Report on Mutual Aid Agrements for Radiological Transportation

Eimeresencies (May 1990) (DOE/CH/104(12-4)

Model State Mutual did Agrecment (December 1990)

(DOE/ $/ \mathrm{CH} / 1(1) 4(12-5)$

Midterstern High-Le'del Radionction Waste Transportation Primer (May 1991) (D)E/(C11/104()2-9)

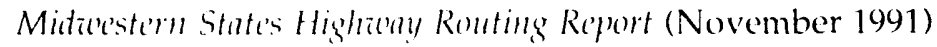

(DOE $/ \mathrm{CH} / 1(1) 4(1)-\mathrm{I}(1)$

Timing and Funding of Emergency Response Training in Midzestern

Stute's (November 1991) (DOE/CH/10402-14)

Highingy Infrastructure Riport (February 1992) (DOE/CH/10402-16)

Index of Ainilatld Re'source's (May 1992) (DOE/RW/104(1)2-18)

Handbook of High-Le'te'l Radionction Waste Transportation

(October 1992) (DOE/CI// (1)4(1)2-19)

To order publications, indicate the number of copies you wish to receive, complete name and address information below, and send this form to

MIDWESTERN HIGH-LEVEL RADIOAC IIVE WASTE PROJECT

THE COUNCIL OF STATE GOVERNMENTS

641 E. BUTTERFIELD ROAD, SUITE 401

LOMBARD. IL 60148-5651

312/353-0813 (FAX)

Name:

Company:

Address:

Phone: 


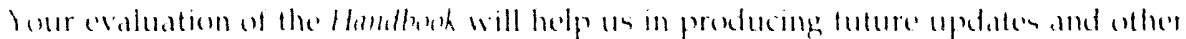

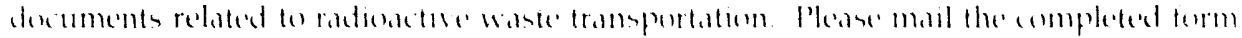

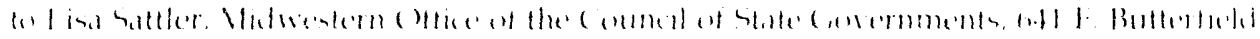

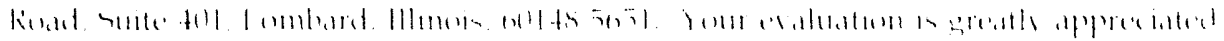

1. Ilas vent knowledge of radiontive wante tramsportation increased an a result of the intormation presented in the Hambllake?

$$
\text { ien } 111
$$

In what renpoct?

2. Will the information in the llandlynk be usetul in policymahing ar program develop. me'nt in renur state?

$$
\text { ine } 111
$$

In what renpert?

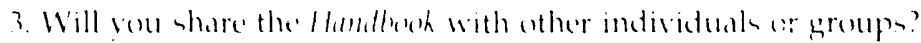

rin

If ves, whe?

4. What areas do gen winh the Hamdlesh had covered in greater detail?

7. Are there aresin on which vou think the llamellent prosided too much detail? l'es no

It ve's, what?

6. Do vou have ans lurther comments? 

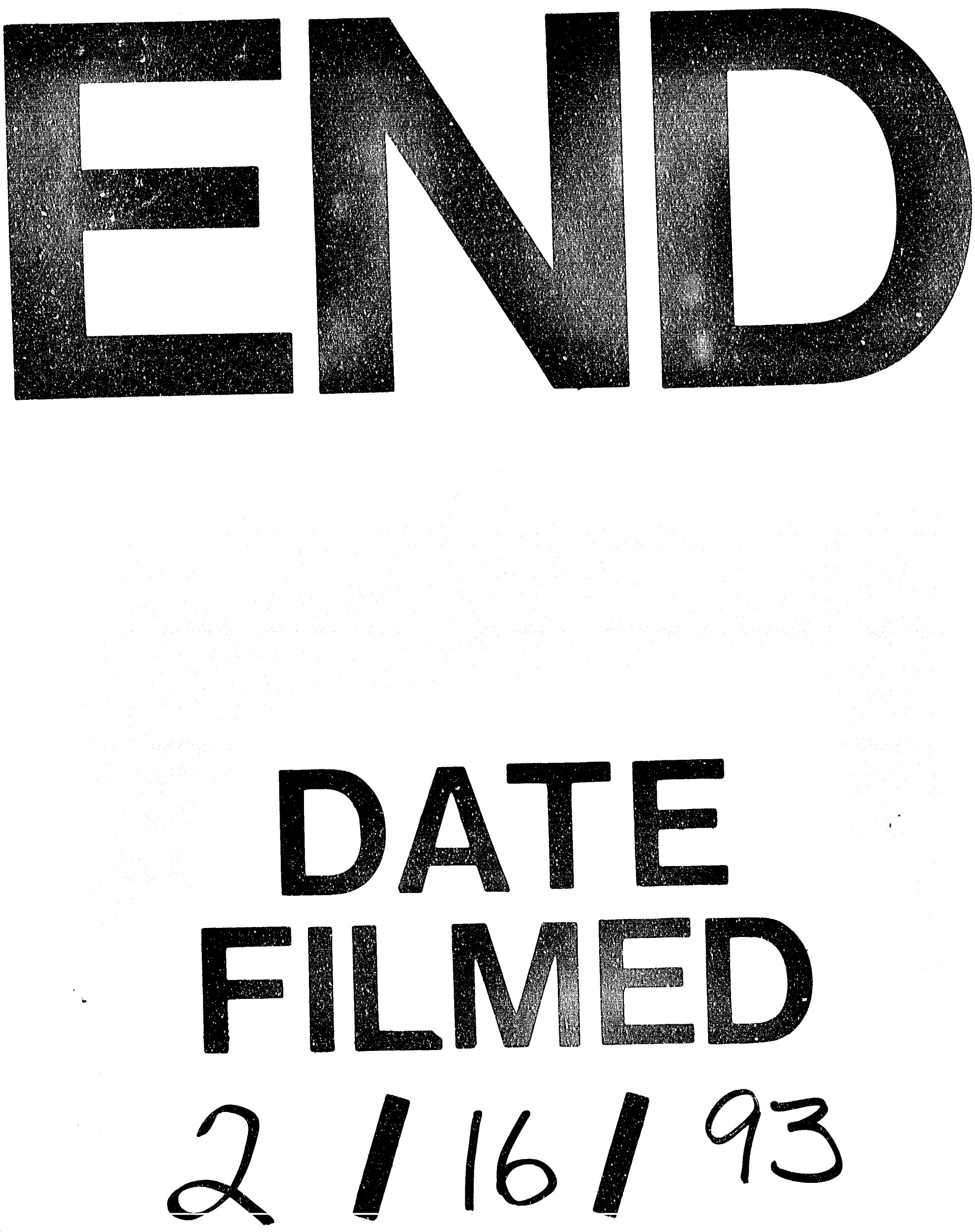
